\title{
WestVirginiaUniversity
}

THE RESEARCH REPOSITORY @ WVU

Graduate Theses, Dissertations, and Problem Reports

2002

\section{Physical emergence}

\author{
Scott Leon Smith \\ West Virginia University
}

Follow this and additional works at: https://researchrepository.wvu.edu/etd

\section{Recommended Citation}

Smith, Scott Leon, "Physical emergence" (2002). Graduate Theses, Dissertations, and Problem Reports. 1240.

https://researchrepository.wvu.edu/etd/1240

This Thesis is protected by copyright and/or related rights. It has been brought to you by the The Research Repository @WVU with permission from the rights-holder(s). You are free to use this Thesis in any way that is permitted by the copyright and related rights legislation that applies to your use. For other uses you must obtain permission from the rights-holder(s) directly, unless additional rights are indicated by a Creative Commons license in the record and/ or on the work itself. This Thesis has been accepted for inclusion in WVU Graduate Theses, Dissertations, and Problem Reports collection by an authorized administrator of The Research Repository @ WVU. For more information, please contact researchrepository@mail.wvu.edu. 
Physical Emergence

Scott Leon Smith

\begin{abstract}
Thesis submitted to the College of Creative Arts At West Virginia University In partial fulfillment of the requirements

For the degree of
\end{abstract}

\author{
Master of Fine Arts \\ In \\ Acting \\ Peggy McKowen, Chair \\ Jerry McGonigle \\ Phillip W. Beck \\ Kate Udall \\ Jessica Morgan
}

Division of Theatre and Dance

Morgantown, West Virginia

2002

Keywords: Physical Acting, Stanislavsky, Creating Characters

Copyright 2002 Scott Leon Smith 


\section{Abstract \\ Physical Emergence}

\section{Scott Leon Smith}

An examination of the physical development of characters through improvisation and experimentation. The physical process of acting is a vital part of creating characters for the stage. This thesis is about the discovery of the value of that system, and finding a trust in the process of physical character development. 


\section{CONTENTS}

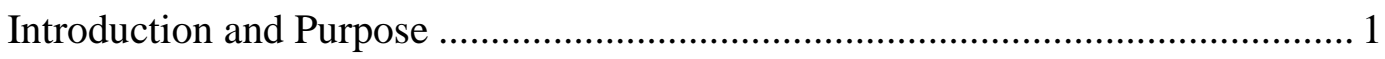

Sec. I. The Impotence of Being Interns......................................................... 2

Early Development

The Process in General

Lane: The Gliding Geilgud

Bracknell: The Bearded Lady

Cecily: The Blonde Scots-Girlyman

"Earnest" in Performance

Sec. II. A Not-So-Wonderful Life................................................................ 12

Background Work

The Wheelchair Dilemma

Last-Minute Specifics

"Wonderful Life" in Performance

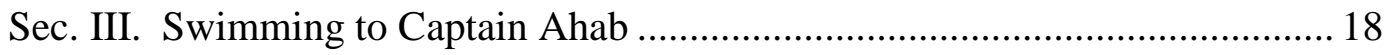

Physicalizing the Past

"Moby Dick" in Performance

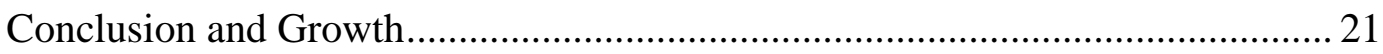

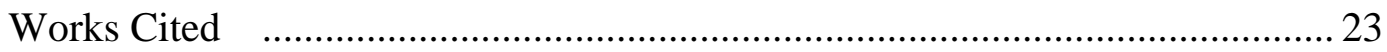


Scott Leon Smith

\section{INTRODUCTION AND PURPOSE}

"...the physical materialization of a character to be created emerges of its own accord once the right inner values have been established."

--Constantin Stanislavsky Building a Character

I've made a discovery recently that Stanislavsky's statement functions on two different

levels. Not only does the inner value system of a character inform that character's physical life, but a personal faith in the physical process also provides the foundation of developing a character's physicality. Moreover, and actor must hold a firm belief in the value of physical experimentation. This year, I've had the opportunity to play five roles, all of which demanded very specific physical lives: Lane, Lady Bracknell, and Cecily in The Importance of Being Earnest, Mr. Potter in It's a Wonderful Life, and Captain Ahab in Moby Dick. In portraying these characters, I have discovered that my personal connection to them was the determining factor in making their physical lives wholly specific. However, that personal connection did not arrive unless I had faith in the physical process.

In the past, my personal rehearsal process had rarely included self-motivated physical experimentation. I established my characters' inner-value systems through mental analysis. This practice was part of my value system as an actor. However, by only mentally analyzing my characters, I've discovered that my personal connection with them was not as strong because I had not experimented with them in a physical manner. As a result of my experiences this year, I've reached the conclusion that physical experimentation must become my primary tool for developing a character. It is the determining factor of my success in performance; and it must become part of my inner value system as an actor.

In this document, I will discuss the physical development of the five characters that I've mentioned above. I will first discuss the techniques, textual clues, inspirations and/or 
impersonations that were utilized in their physical evolution, and secondly, the defining elements of rehearsal that either helped or hindered my personal connection with their physical lives. I will also reflect on my overall success in performance, and will cite the insights of familiar theorists to determine why I failed or succeeded. This is not a chronicle of three separate rehearsal processes; the objectives, obstacles, and intentions of the characters are not the paper's primary focus. The main purpose of this thesis is to examine my process of character development and discuss how physical experimentation has allowed me to grow as an actor.

\section{I: THE IMPOTENCE OF BEING INTERNS}

\section{Early Development}

What intrigued the Graduate Class about a four-person version of Oscar Wilde's The Importance of Being Earnest was the fact that we would be responsible for bringing nine different characters to life. The possibilities of switching between roles, playing different statuses, genders, and physicalities; and the imminent silliness that was sure to ensue added a great deal of excitement to the project.

During our first rehearsals, the five of us: myself, Michael Rashid, Nina Domingue, Dan Forsythe, and director Phillip Beck addressed the very important question of how we would present the play. Professor Beck told us a story about a production of "Earnest" he had seen where the actors played doors and pieces of furniture. So it was not completely out of the question to do a version of "Earnest" that did not adhere religiously to the fashion and physical acting of the period in which it had been written. Through our discussions, we hit upon a concept that was, for me, was extremely inspirational. 
The concept was this: Four interns in the trap-room of a theatre cleaning up after the end of the season; They find a copy of the "Earnest" script and begin to entertain themselves by acting it out, using whatever props, costumes, and set pieces were at hand.

Professor Beck further developed this concept with the idea that the interns would be sucked into the story and experience the need to finish the play no matter what. They would be forced to decide, in the moment, how to move the story. So, in effect, we would not only have to switch between the physicalities of the characters, but change from our own physicalities to those of our characters; in the moment and in full view of the audience.

\section{The Process in General}

Rehearsing "Earnest” was an exercise in freedom. The freedom to explore and experiment; with physicality, voice, and costumes, became the most important part of the process and the foundation of my personal connection with my characters. I was very happy that Phil was lending his energies to keeping our objectives and intentions on track so we could have the freedom to experiment physically.

I was also grateful to Jessica Morgan, our Movement professor, for providing lessons in Rudolf Laban's Theory of Movement. I often used Laban's Effort Qualities as a starting point in the development of my characters' physical lives. The Effort Qualities that Laban created are discussed in more detail in Jean Newlove's book Laban for Actors and Dancers. In my particular process for "Earnest", the basic ideas and techniques of physicalizing those Effort Qualities were enough to get me started.

The basic structure of Laban's Movement Effort Qualities is based on the three continuums of Time, Weight, and Space: The Time of the movement could be sudden or sustained; The Weight, light or strong; and The Effort Quality direct or indirect. All eight of 
Laban's Basic Movement Qualities contain one aspect of all three continuums. Those eight qualities are: 1) Press: direct, sustained, strong [doing a push-up]; 2) Flick: indirect, sudden, light [shooing a fly]; 3) Wring: indirect, sustained, strong [twisting a wet towel]; 4) Dab: direct, sudden, light [typing]; 5) Slash: indirect, sudden, strong [backhand in tennis]; 6) Glide: direct, sustained, light [sledding]; 7) Punch: direct, sudden, strong [self-explanatory]; 8) Float: indirect, sustained, light [as if your body is smoke] (Newlove, 68-85). In movement class, Jessica would ask us to think of our characters' physical and vocal lives in terms of these eight "Effort Qualities." Our character may embody only one of these qualities or any combination of them.

\section{Lane: The Gliding Geilgud}

The physical life of Algernon's servant Lane, emerged from experimenting with Laban's Movement Qualities and the impersonation of one of the world's greatest actors. In thinking of Lane's movement quality, I began to see him as a "Glide." His movement would carry him directly and at a sustained pace through space, and he would handle objects lightly and efficiently as any butler in a wealthy home would.

His gliding quality was justified in my mind by various clues found in the script. Oscar Wilde describes Lane as having "the quiet solemnity of the distantly tolling church bell"(66). This image called to my mind the idea of Lane being a sort of drone; moving quietly throughout the house like the sound of distant church bell moving through a village. In all of his scenes, it also apparent from his speech that he was bored and unimpressed by his master, Algernon. This gives him that quality of distance. So, he would not be a hop-to-it, flick-like kind of butler who is constantly preening his employer and doing everything he can to please him. He would carry out his duties efficiently, but with little reverence to his master or respect for his master's status. 
The "church bell" image also gave me ideas as to the way Lane might speak. Although the drone of a church bell is very direct in its sound, it also contains a floating quality as the sound dissipates. So, I thought perhaps Lane would float through his speech using a lot of intonation and vocal variety. Then another image popped into my head (I was shocked that it hadn't before); an image of John Geilgud as Dudley Moore's butler in the film Arthur. I thought, "That's Lane!"

As it turned out, that image of Geilgud provided the inspiration I needed to specify Lane's physicality. Now, it is important to note that in a normal rehearsal process I would strenuously avoid doing impressions of other actors as a basis of my performance. However, our concept for Earnest encouraged me to ignore that principle and spin old Stanislavsky in his grave. After all, we were supposed to be interns having fun, entertaining each other, and making things up as we went along. Doing impressions of our favorite actors and characters has been a long-standing ritual and constant source of entertainment in the Graduate Acting Office. As a result, doing impersonations as part of our characters' physical and vocal lives became a compliment to our concept and enhanced our personal connection with the play.

That personal connection through physical impersonation--added to the Laban work that we did in movement class--would not only solidify Lane's physical life; but would also serve as the catalyst for the development of and experimentation with our other characters.

\section{Bracknell: The Bearded Lady}

My physical portrayal of Lady Bracknell was initially inspired by the work of John Cleese, Eric Idle, Graham Chapman, Terry Jones, and Michael Palin, the geniuses that created the sketch comedy of Monty Python's Flying Circus. Their tinny-voiced, cross-dressed 
portrayals of typical British housewives, with unshaven faces and hairy knuckles clutched tightly to small purses, were the perfect reference for my creation of Bracknell's physicality.

Quoting Monty Python sketches and doing impersonations of my favorite Python characters has been a part of my life since I was in middle school. As I stated before, impersonation became a large part of making a personal connection with my characters. I felt that by making Lady Bracknell a "Python-esque" woman, I could solidify my personal connection with the role and create a greater means of success in the physical development of her character. However, I knew that she could not be completely Python-esque. Bracknell, of course was not a kooky, passive British housewife. She was a kooky, powerful, suspicious, narrow-minded, direct, and tyrannous British housewife. I decided, that although the typical Python woman could be used as her inspiration, it could not be completely present in the final product.

As with Lane, my first clues for developing Lady Bracknell's physicality came from Oscar Wilde's exhaustingly detailed descriptions of her in the text:

Lady Bracknell carries herself with the regal dignity bred in her by her ancestry, indoctrinated by childhood training, and burnished by years of unquestioned domestic tyranny...there can be no question of her divine right to govern, to make all social arrangements. Her will is that of the cosmos, her tone that of an oracle, her manner as imperious as would be expected of one bearing the name of Augusta (Wilde, 76-77).

The inspirational phrases that I gleaned from this description gave my portrayal of Bracknell a physical jumpstart. Phrases like 'regal dignity,' 'unquestioned domestic tyranny,' 'divine right to govern,' and words like 'cosmos,' 'oracle,' and 'imperious' became the foundation of her physical life. 
My first experiments with her movement through space centered on the technique of Leading that was introduced to the graduate class by Jessica Morgan. In class, we would work on leading with specific parts of our bodies. We would imagine, as we walked, a string pulling on a shoulder, an ear, an eyebrow, etc. This image would then affect the way we walked and carried our bodies through space and allowed different characterizations to emerge. The Leading technique became very valuable in helping me develop a very specific physicality for Lady Bracknell right from the beginning of the rehearsal process.

Words from Wilde's description of Bracknell like regal, dignity, divine, cosmos, and imperious resonated with me while working with the concept of Leading. To me, all of those words indicated something high above, untouchable, and omnipotent. The words also indicated to me a sense of pride, narrow-mindedness, and directness. When experimenting with her movement, I imagined a string on my chest pulling up and away as I walked. By doing this, I felt a sense of pride. I often felt myself towering over my fellow actors as we rehearsed, feeling very strong, willful, and powerful.

I also experimented with the condescension and scrutiny that was very inherent in Bracknell's character. I thought that a woman of high status would often, if not always, look down upon those around her; 'down her nose' at those who had displeased her or those of whom she was suspicious. So, I added an imaginary string to my nose, pulling me toward my fellow actors and leading me in different directions around the space as if I were looking for something to criticize.

However, even with the technique of Leading at my disposal, Bracknell's physical life did not take on its complete specificity until later in the process. Throughout rehearsals, the imagining of strings, the inspiration of Monty Python, and the images of Wilde's character 
descriptions were serving me well, but didn't seem to be enough. Jessica Morgan sat in on a few rehearsals and told me that the physicalities of all three of my characters were bleeding together. The way Lane walked was a little too close to the way Bracknell walked. There were also some facets of Cecily that were present in Bracknell's quality of movement. As a group, we were still developing our methods of switching between characters, and perhaps that was the reason for the problems I was having differentiating between my three characters. But to me the solution to specifying Lady Bracknell's specific physical life was clear. I needed a costume.

Division Chairperson, Peggy McKowen, agreed when she saw some of our later rehearsals. Up until a week before the show was to open, I had been using a mink stoll, a purse, and whatever shirt I happened to be wearing wrapped around my waist as a skirt. She wanted something bigger and more elaborate. As we began rehearsals in the studio theatre, she provided me with a large, bulky skirt, a mangy red wig, hat with plumes, and a pair of high-heeled boots to add to Bracknell's ensemble.

Of course, as I believe it does with the development of any character, the costume made all the difference. The high-healed boots raised me above everyone. The skirt helped me to attain a larger than life presence. The wig gave me a very narrow field of vision so that my focus could be very direct. I felt all of the physical qualities I had been striving to achieve: the power, the dignity, and the constant scrutiny, the narrow-mindedness. All of the work I had done with Leading and all the inspirations of Wilde and Python seemed to live inside the costume with me. Lady Bracknell had come to life.

\section{Cecily: The Blonde Scots-Girlyman}

I could, for the sake of hindsight, talk about all of the Laban movement qualities that were present in Cecily's physicality. I could examine what parts of her body led her through 
space and developed her physical life. But, I would be lying. Cecily, was one of those roles that an actor dreams of playing. She was a role that required very little work because my idea for her physical life was so inspired, and my trust in the instincts of my fellow actors was so implicit, that Cecily just happened.

As we were first getting "Earnest" on its feet, Professor McKowen provided the cast with a bunch of miscellaneous costume pieces. We, like eager children, plowed through the costumes frantically searching for something that vaguely or perfectly represented our characters. Up until this time, I'd been amusing Michael, Dan, and Nina by experimenting with Cecily's vocal qualities. Sometimes I would read her lines in a high-pitched RP dialect, sometimes in Cockney. I even fiddled around with Latin, Southern, Valley Girl, and Pakistani dialects. But all of that changed as I rummaged through the plethora of clothes that Professor KcKowen had brought.

I found a plaid bathrobe that I thought would make a good skirt for Cecily. I had images of her possibly being a Catholic Schoolgirl type, and thought maybe the skirt could show that off, somehow. Then I found a scarf amidst the piles of clothing that I used as a sash. I tucked it into the robe that I'd wrapped around my waist and threw it over my shoulder. I thought: "I look like Braveheart...!" The portrayal of Cecily as Scottish man/girl was conjured just from that simple choice of costume.

There were of course, some inspirations from Wilde's description of Cecily that helped me with her physicality: "Her simple, open-air freshness of style and manner do not entirely conceal a determined and confident nature"(94). 'Open-air freshness' was the phrase that captured my attention. I got an image of Cecily as this virile Scotsman/woman who was oozing with hormones and so sweaty with sexual anticipation that she had to constantly air herself out. So, I began moving with my arms hanging out to the side and swinging as if I were airing out my 
armpits; and walking with my legs slightly apart to air out the underside of my 'kilt.'

Disgusting, I know, but this saunter really felt perfect for the character. I put on my silliest Scottish dialect with my new sleazy saunter; and went to work.

As rehearsals continued, my work with Cecily's physicality became simply about letting it happen and adding more specific details to it. That specificity came from making choices about when her feminine qualities would take more control and when her masculine qualities dominated. My work with Michael Rashid who played the role of Algernon helped me to make these decisions.

Michael's presence as Algernon often dictated the changes between Cecily's masculine and femine physical characteristics. I found I could just let the Cecily physicality take over and develop on its own. The sleazy and masculine qualities of her movement often changed as Algernon interacted with her. She became a little more reserved, girlish, and shy. My arms would stay close to my sides and I would make a vain attempt at keeping my legs closed as a proper English girl would. Then, as Algernon and Cecily got to know each other and their passion increased, Cecily's movement became even sleazier and her hermaphroditic sexuality exterted itself with astounding vigor.

Along similar lines, Nina and Dan's work with their characters also determined various specific aspects of Cecily's physical life; in particular, Nina's work in the role of Gwendolen. As Cecily met Gwendolen, whom she believes to be her rival for Algernon's affection, her masculine traits took control. The 'fight scene' with Gwendolen was pure masculine protection of territory for Cecily. Her highlander side revealed itself in all of its testosterone-laden glory. With Dan in the role of Marilyn (Merriman), Cecily's feminine traits were dominant. For Cecily, Marilyn became a female confidant, a best friend with whom she could share all of her 
adolescent secrets. When interacting with Marilyn, Cecily would take on the qualities of a teenage girl, bubbling with excitement, and giddy with a lust for all things taboo. As rehearsals went on, I was pleased to find that my reactions to my fellow actors made Cecily's physical life even more specific.

\section{“Earnest' in Performance}

The Opening Night of "Earnest" was a night of anxious tension. I was very excited about the work I'd done and hoped that it would pay off. The question was: would the concept work? The cast had put the lion's share of tomfoolery and ridiculousness into the script and enjoyed the silly roles that we had created. But I was worried that all of the gimmicks, gags and in-jokes would take the audience's attention away from Wilde's plot.

I remember standing off-stage with Nina, Michael, and Dan trying to work through all of my nervous energy. I felt something that I hadn't felt as an actor in years: fear. I truly didn't know if what we had would work. We shared a cast hug, and I felt my fear turn to anticipation. The simple physical act of being close to three actors whom I trusted implicitly was enough to alleviate my anxiety. I couldn't wait to get onstage and live as my characters.

Looking back on that moment, I know I would not have been able to re-create my characters' physicalities if I hadn't trusted my fellow cast members. As I interacted with them, it was easy to step into every physical lives that I had created. I believe all four of us had a very personal connection to this project; and, ultimately it was this connection and our implicit trust of one another that made "Earnest" such a success. 
Scott Leon Smith

\section{II: A NOT-SO-WONDERFUL LIFE}

Portraying Mr. Potter, the bitter, evil nemesis of George Bailey in our stage production of It's a Wonderful Life, was one of the most frustrating experiences of my acting career. It was, in my opinion, a most dismal failure. After every performance, I received compliments and congratulations from fellow actors, patrons, and professors that I took with grace and appreciation. But there was always a nagging voice in my head that preached dissatisfaction. While developing this thesis, I reflected on my work with Mr. Potter's character, and tried to discover what mistakes I had made. I discovered that what, in fact, made my experience so negative was that I'd brought most of the frustration I felt on myself.

As I stated in my introduction, Stanislavsky's statement from Building a Character: “...the physical materialization of a character to be created emerges of its own accord once the right inner values have been established" (3), functions on two different levels. When I looked back on my work on It's a Wonderful Life, I found--in my struggle to bring Mr. Potter to life-that I that had compromised my own inner value system. This caused me great difficulty in establishing Potter's inner values and thus hindered the materialization of his physical life.

When I was cast as Mr. Potter, Director Jerry McGonigle told me that he had so many young faces in the cast and needed someone with a more mature face to play the aged, devious Mr. Potter. While I was thrilled to be playing a villain, I thought: "Great, another old man. I'm twenty-seven years old, and already a character actor." I've always had an aversion to deepening the lines in my face with make-up and spraying layers of silver into my hair. My journal entry after our first read-through of It's a Wonderful Life was one sentence: "I hate playing old people." 
Even as I write, I can see how I was doomed from the beginning of the process. I should have placed some kind of value on the experience instead of classifying it as "just another agerole.” Because of my poor value system then as an actor, I destroyed any chance of establishing a personal connection with the role of Potter; let alone creating his specific physical life.

\section{Background Work}

Dreading the inevitable moment when I would pencil-in the deep age-lines and crust my hair in toxic silver, I set to work on the role of Potter. I started with his past. I believed that if I could make his past experience very specific, I would be better prepared to experiment with his physicality. As Uta Hagen wrote in Respect for Acting: "My aim is to give myself new roots, to make all of the elements of 'my' life up to the play's beginning as concrete as I can, until I know as much as possible about the new 'me'"(153). Although I wasn't particularly excited about the new "me", I tried to focus on a part of it that would interest me creatively. Potter's past was the aspect of his role that most interested me, so I felt that if I did enough work with his life up until the beginning of the play, I could establish a more personal connection with him. This would in turn allow me to make his physicality specific.

In the script that Dr. J. Malarcher developed, as in the original screenplay, there is no mention of how Potter became disabled. One of the first insights Dr. Malarcher gave me into Potter's character was the fact that the actor in the film It's a Wonderful Life, Lionel Barrymore, was suffering from polio. In Barrymore's case, Potter's wheelchair was a practical necessity rather than a character choice. For me, every nuance of Potter's physical life would be chosen and specified through his history.

Throughout the first weeks of rehearsal, I tried to answer various questions like: Was Potter born an invalid or was he the victim of an accident that cost him the use of his legs? Did 
he use his disability to attain his place in Bedford Falls? What did George Bailey's father do to incur Potter's wrath on his entire family? Was Peter Bailey the cause of Potter's disability? The answers to these questions were the most intriguing part of my work and were very important in specifying how Potter lived in his wheelchair. However, these questions were never fully answered because of my frustrating struggle with the wheelchair itself.

\section{The Wheelchair Dilemma}

The wheelchair was the double-edged sword of my "Wonderful Life" rehearsals. I was glad to have the wheelchair from the beginning of the process, but it turned out to be the one aspect of my character that I struggled with until the performance.

What hindered me most in working with Potter's physicality was the construction of the wheelchair itself. It seemed to take me out of the action of the scenes. Even in it's most upright position, the wheelchair would cause me to recline as I sat in it, which made me feel very far away from my fellow actors. I was slumped and immobile which took away from the power and aggression that I felt were the most important part of Potter's physical life. He was an invalid, to be sure, but I wanted him to exert himself in such a way that would almost bring him out of the wheelchair.

Jerry agreed with this choice. Throughout the process, he would always suggest to me that Potter needed to have a larger than life quality in his movement. We would be performing on a large stage in front of a very large audience, so it was important that every audience member would be able to see Potter's aggression through his physicality. But the immobilizing effect the wheelchair had on my body did not easily allow me to achieve the animated quality that Jerry wanted. 
I still felt slumped and distanced from what my fellow actors were doing. And when I tried to be animated I felt very mechanical and unrealistic. I would talk with my arms, point my fingers, pound on the arms of the chair, and raise my fists in melodramatic anger. Everything I tried to do to bring myself out of the wheelchair and attain a larger than life quality felt fake and unspecific. The immobilizing effect of the wheelchair was dominating my physicality too much, and experimenting with different physical qualities became very frustrating.

During one rehearsal, Jerry suggested that: while helpful to me as an actor, the background work I was doing didn't seem to be serving me in rehearsals. I was too interested in events outside of the play and not focused enough on my moment-to-moment interaction with the other characters. If I focused on the present instead of the past, I might be able to find Potter's physicality more quickly. Time was short and the performance dates were approaching very rapidly.

But, my belief that I could play the character had already been compromised by my poor attitude as an actor. Rather than negatively judging every physical thing that I'd tried, I should have been more committed to my physical experimentation and had more belief that I could actually play the role. Consequently, Potter's physicality was not specified until very late in the process. And because of my inability to specify his physical life, I had difficulty dealing with the action of my scenes and could rarely silence the voice of self-judgment in my brain.

\section{Last-Minute Specifics}

The degree of specificity that I finally attained with Potter's physicality came through the issue of practicality. As we started rehearsing on the Concert Theatre stage, I realized that there was no way that I could be rolled onstage in my wheelchair. There were no ramps leading up onto the platforms. So, my wheelchair would have to be placed on a platform while I walked out 
in full view of the audience. I felt that if I just walked out, the illusion of my disability would be ruined for any audience member who cared to scrutinize. So, I made a very hasty decision: Potter would have to have some use of his legs.

I requested a cane from Props and hobbled out with it for all of my scenes. To exit the stage, I pulled myself painfully out my wheelchair and hobbled off. Jerry and several others assured me that if I simply walked onstage; darkness allowed by the lighting design would mask me from the audience. But, I was so completely frustrated at this point in the process that I felt I had to make something about Potter specific, or I would feel absolutely no connection to what I was doing. The choice to use a cane turned out to be the one beneficial discovery that came from my weeks of work.

During later rehearsals, I incorporated the cane into all of my scenes. I would always have the cane close to me. I would grab it and swing it around in moments of anger or bitterness. It gave me a feeling of power and a quality of being larger than life, which pleased Jerry. I even began my last office scene with George Bailey standing with the cane and looking out an imaginary fourth-wall window. As George entered, I felt an awkward need to be in my wheelchair again, and hobbled to it as quickly as I could. Jerry liked the choice and asked me to develop it further. I thought: "I'm finally being specific." I finally began to discover small parts of Potter's physical life. But, it was too late in the rehearsal process. I was still struggling with my objectives because of my long bout with Potter's physicality. And would continue my struggle all the way through the run of the show.

\section{“Wonderful Life" in Performance}

In An Actor Prepares, Stanislavsky said: “...when an actor comes out on the stage before an audience he may lose his self-possession...from a sense of overwhelming responsibility or 
unsurmountable difficulties. At that moment he is incapable of speaking, listening, thinking, wishing, feeling... or even moving, in an ordinary human way" (248). Looking back on the performances of It's a Wonderful Life, I realize that I had lost my self-possession. In my case, it was lost because of my belief that my difficulties could not be overcome; and because of my lack of faith in what I was doing.

During every show, the nagging voice would never silence, and I became more and more infuriated by my unspecific physical gesturing. The cane was the only element of my physical life that I could rely on. But since it was added so late in the process, I was experimenting with it even as I was on stage in performance. The voice in my head was constantly droning: "you're experimenting when you should be listening and living in the moment." Everything I did felt fake and unspecific, because I had failed to possess Potter's physical life and because I was not in full possession of my own self-belief.

I scuffed up to the dressing rooms fully relieved that the experience was finally over. I looked at the young face in the mirror, crusted with fading make-up; and my sprayed gray-hair that had fallen out of place and thought, "What did I just do?" Jerry came into the dressing room, gave me a hug and said, "You finally found it." At that moment I felt that had let him down. He believed so much that I could play Potter and I had absolutely no belief in myself. Throughout the rehearsal process, he told the cast about his personal connection with the story and his belief in its importance. I felt angry with myself because I didn't have that personal connection; and didn't believe that I could find it.

Stanislavsky said: "Truth on the stage is whatever we can believe in with sincerity, whether in ourselves or in our collegues" (An Actor Prepares, 122). In "Earnest", I gained a renewed belief in my acting process through the discovery that I could find a character through 
physical experimentation. In "Wonderful Life", my belief was absent because, I approached the role of Mr. Potter as I had in the past: without enough physical experimentation. I had intellectualized my character instead of improvising his actions. I believe the reason was that the "Earnest" project was so unconventional; and I truly felt that any experiment was appropriate. When faced with a conventional story, I reverted to my intellectual routine and scrutinized every physical choice. As a result, Potter's physical life was unspecific, unconnected, and above all, untruthful.

\section{III: SWIMMING TO CAPTAIN AHAB}

I'd decided from the beginning of rehearsals for Moby Dick that I wasn't going to succumb to the self-judge-mental negativity that hindered my work with Mr. Potter. I wasn't going to let Captain Ahab's age be a factor in dictating my ability to play his role; and I was going to re-invest myself in the process that had helped me bring my "Earnest" characters to life.

I discovered early in the process, that the few physical characteristics that I had specified for Mr. Potter turned out to be very beneficial in creating Ahab's physical life. In fact, the two characters were so similar in age, in intention, and in physicality, that I felt it would be ridiculous

to ignore my work with Potter. Both Ahab and Potter were disabled, angry, and aggressive. And both wanted control over something that they could not possibly dominate. Physically, I decided, Ahab would have to experience pain as he hobbled around on his destroyed leg. This idea was taken directly from my work with Potter and his use of a cane.

To compliment the ideas I had about Ahab's physical life, I sought inspiration from a book called Physical Characterization for the Actor. In this text, actor/director David Alberts discussed aspects of different character types to be used as a foundation of discovering 
characters. I was surprised to find my inspiration for Ahab's physicality written in this text. The character type, Schizoid, was described by Alberts as having the following traits:

Narrow body, tight and rigid. Tension in the neck, shoulders, pelvis, and legs. Moves stiffly, and not at all gracefully. Pale skin due to poor circulation. Always feels cold. Body misaligned, asymmetrical...Shallow weak breathing. Blank unemotional mask like face. Arms hanging dead and inexpressive at sides. Gestures minimal and restrained. Long inner life struggle is graphically represented in the body (Alberts, 76-77).

As the cast of Moby Dick began our physical experimentation with our characters (again using the Leading technique that Jessica Morgan had introduced to us), I kept these images in my mind. However, I made a definite effort to let the image inspire Ahab's physical life rather that trying to physically replicate the images.

\section{Physicalizing the Past}

Ahab's physicality gained its greatest specificity when I presented to the cast a movement piece that briefly chronicled various events from his past. Since background work had not been fully completed for Potter's character, I felt strongly that Ahab's past must be dealt with in order to give meaning to his on-stage physical life. The movement piece depicted all of Ahab's lifechanging-moments events that are described or dramatized in Mark Rosenwinkel's stage version of Moby Dick. The most important events being 1) Moby Dick's devouring of Ahab's leg, 2) Ahab's decent into madness, 3) Young Ahab killing his first whale, 4) Ahab's final confrontation with Moby Dick. Added to these major events, I decided to examine events from Ahab's past that were not mentioned in the script: 1) Young Ahab on his first voyage, and 2) Ahab's rise in the ranks as a Sea Captain.

As I worked on the movement piece, I again utilized the Leading technique and discovered that Ahab tended to lead with his devoured leg. I imagined my left leg as a gnarled 
ivory stump. I locked my knee and stiffened all of my leg muscles. I then imagined a string leading the stump as I moved. As I did this, my body became very rigid and I began to feel a great deal of difficulty in performing the simple act of walking. I began to sweat and become impatient that I was not getting anywhere quickly. It took a great deal of effort to sit down or climb to the top of one of the set pieces. In essence, I began to feel everything that Ahab would feel. As a result of this simple experiment, I began to develop a physical and personal connection with Ahab's character.

However, what was most interesting about this experiment was how Ahab's physical life before the loss of his leg justified the choice that he would lead with it. As I worked on Young Ahab's physicality, I improvised him boarding his first ship, scrubbing the decks, climbing to the crows' nest, and rowing a boat in pursuit of his first whale. All of these improvisations were inspired by Ahab's line to Ishmael: "Methinks I see myself in thine eyes" (Rosenwinkel, 31). It was clear to me that Ahab and Ishmael were connected in some way. I felt that young Ahab's physicality might slightly mirror the physicality of Ishmael. As I continued to improvise Ahab's young life, I discovered that Ahab led with his heart. This allowed me to discover Ahab's connection with the character of Ishmael that is alluded to in the text. They were connected by a common spirit of adventure. I felt it befitting that they would both lead with their hearts. The difference with Ahab was that the loss of his leg changed the part of his body with which he led. The adventurous spirit was gone and all that was left was a thirst for revenge. The revenge he sought was embodied in the constant reminder of his lost leg.

By physically developing Ahab's life up to the point of the play's start, I was able to formulate his physical life from the beginning of the rehearsal process. Throughout the many weeks of rehearsals there were times when I would lose the specificity of the movement I'd 
developed, but I always had the movement piece to go back to as the blueprint of Ahab's physical life. It was something that I'd created myself. And because it was such a successful experiment, I was able to gain a greater personal connection with the character that was always present in his development.

\section{Moby Dick in Performance}

My physical portrayal of Captain Ahab was very successful in performance for many reasons: Primarily, because extensive physical preparation allowed me to forget about his physicality. I didn't have to think about Ahab's every movement as I had with Mr. Potter. I simply made my entrance into the environment and let him appear. I made his physicality my own.

Another reason for my success was that my ownership of the character's physical life allowed me to adapt my performance for a variety of different spaces. Whether I was in the cramped VDM Lab Theatre or a cavernous high school gymnasium, my physical work allowed me to make adjustments in Ahab's character to accommodate the limitations of any space.

\section{CONCLUSION AND GROWTH}

It has been a common criticism among my instructors that I am too intellectual in my approach to acting; that I often mentally predetermine various aspects of my characters. As a result, the most important parts of my characters, their actions, are not dealt with early enough in my process. As Uta Hagen wrote: “The sum total of the actions...reveals your character...[and] must tell the story of the body and soul of your character" (185). I have ignored the value that physical experimentation can have in discovering a character's physical traits and focused more on determining in my mind what those traits should be. 
I feel that my work this year has allowed me to take steps towards alleviating this problem. By exploring characters with very specific physical lives, I've added an element of physical experimentation to my acting process. I have finally discovered that the presence or lack of this rehearsal technique is the determining factor of my success in performance.

In the past, my mental approach or attitude toward a role has often caused me to feel frustrated during the process of the character's development. It hindered my personal connection to the role. This was very clear to me in my work with Mr. Potter in It's a Wonderful Life. I tried to justify Potter's movement mentally instead of giving into physical experimentation and allowing his physicality to come on its own. I discovered that my intellectualizing and mental attitude was the cause of my frustration.

In The Importance of Being Earnest and Moby Dick, I found the necessity that lies in physical characterization. I've discovered the personal connection it fosters in me as I develop my roles. I reflect on the fact that their ultimate materialization was not achieved solely from mental analysis, but also from physical inspiration.

As I reflect on the development of these five roles I realize finally what has been stated to me over and over these past three years: "Acting is doing." But, I do not think it is just that. In terms of my personal process, acting is giving into the doing. It is feeling free to physically create and experiment. It is also feeling free from the mental voices that constantly judge my physical choices. But, in order to feel that freedom I must trust that physical process and have faith in its value. 


\section{WORKS CITED}

Alberts, David. The Expressive Body: Physical Characterization for the Actor. Portsmouth, NH: Heinemann, 1997.

Hagen, Uta, and Haskel Frankel. Respect for Acting. New York: Macmillan, 1973.

Newlove, Jean. Laban for Actors and Dancers. New York: Routledge, 1993.

Rosenwinkel, Mark. Moby Dick: An Adaptation of Melville's Novel. Woodstock IL: Dramatic Publishing, 1997.

Stanislavsky, Constantin. An Actor Prepares. Trans. Elizabeth Reynolds Hapgood. New York: Theatre Arts Books, 1948.

---. Building a Character. Trans. Elizabeth Reynolds Hapgood. New York: Theatre Arts Books, 1949.

Wilde, Oscar. The Importance of Being Earnest. Ed. Vincent F. Hopper and Gerald B. Lahey. Woodbury, NY: Barron's Educational Series, 1959. 